\title{
A CIGÁNDI AMERIKÁSOK EMLÉKEZETE
}

Amikor negyven évvel ezelött, 1978-ban elöször léptem Amerika földjére (az Indiana Egyetem magyar lektoraként), a magyar társadalomtudományban kevesen foglalkoztak az amerikai magyarokkal, ki- és visszavándorlásukkal, sikereikkel és kudarcaikkal - akár történelemtudományi, néprajzi vagy nyelvészeti kutatásokra gondolunk. Ez a helyzet előnyére változott a 80-as évek közepén, amikor az MTA és az American Council of Learned Societies együttmüködési szerződést kötött, minek következtében történészek, néprajzosok, nyelvészek, irodalmárok és pszichológusok folytattak jelentős közös (amerikai-magyar) kutatásokat. Az Amerikába utazó magyarországi kutatók egyike Fejős Zoltán volt, aki aztán 1993-ban kitűnő könyvet jelentetett meg a chicagói magyarok etnikai örökségének 1890 és 1940 közötti változásairól. Az 1980-as évek elején még létezett az „amerikai magyarság”, még müködött néhány, száz évvel korábban alapított amerikai magyar városrész, így aztán chicagói kutatásait Fejös nemcsak könyvtárakban és archívumokban folytatta, hanem magnetofonnal rögzített beszélgetéseket is készíthetett öregamerikás bevándorlókkal és gyermekeikkel is. Ma már ez nem lehetséges, mert az egykori magyar „neighborhood"-ok mind elenyésztek, még a múlt század végén. A közösségek alapítói, fenntartói meghaltak, gyermekeik szétszéledtek, a magyar templomok mások kezére kerültek, vagy lebontották öket. A 80 -as évek elején még le lehetett volna fényképezni az amerikai magyar templomokat, temetőket, negyedeket és más emlékeket (magam a Pittsburghben és környékén akkor létező magyar templomok közül körülbelül félszázat láttam), de ezt sajnos senki nem tette meg, így aztán nemcsak az amerikai magyar közösségek enyésztek el, de az ő épített örökségük is nyomtalanul eltủnt, vagy ami még nem tünt el, hamarosan eltünik.

Fejös ebben a könyvében ennek az elenyésző világnak egy jókora darabját megmentette a feledéstől. A könyv a cigándiak amerikai migrációjáról szól alulnézetből. Kiterjed mindenkire, aki Cigándon született, „és felbukkant az Amerikába igyekvők tengerében" (7.). Határozott kritika is a kivándorlás eddig uralkodó megítélését illetően, a személytelen számok helyett, vagyis a „hányan mentek?” kérdés helyett azt vizsgálja, „hogyan történt?” s „mit jelentett?” a kivándorlás a gyakorlatban. A szerző kijelenti, hogy „A migráció jó társadalomtörténetéhez a gyakorlat lehető legaprólékosabb leíró elemzésén keresztül vezet az út" (9.). Célja az, hogy kiemelje a feledés homályából a kivándorlás múltját, „hogy megértsük, mit jelent az, amikor valaki idegenben kénytelen boldogulni” (9.). A térbeli mobilitásnak jelentékeny hagyománya van, ami viszont mára 
nagyrészt elfelejtődött. „Ebben a múltban nemcsak veszteség - társadalmi, demográfiai deficit - rejlik, hanem társadalmi tapasztalat, amely kiaknázható kulturális tőke is" (9.).

A kutatás többfajta forrás feldolgozásával folyt, de , a legföbb kútfőt azok a digitális családtörténeti, genealógiai adatbázisok jelentették, amelyek az Egyesült Államokban keletkezett sokrétü forrásanyagot teszik hozzáférhetővé" (18.). Ahhoz, hogy a Cigándról az Egyesült Államokba vándorolt magyarokat kutassa, Fejősnek nem kellett Amerikába utaznia, ma már online hozzáfért például a „New York Passenger Lists, 1820-1957”-hez (URL1). Jelenleg mintegy hetvenmillió bevándorlási rekordra kiterjedő adatbázisokban lehet kutatni, igaz, a szövegfelismerő szoftverek problémái és a zömében kézzel írt jegyzékek nehezen olvasható volta sok nehézséggel is jár. A kutatás alapját adó forrásbázis 546 nevet ölel fel (32.), a teljes lista a könyv III. részében olvasható. Ez azonban nem jelenti azt, hogy ugyanennyi kivándorló személyről szól Fejős könyve, mivel - egy kirívó példát említve - a Fodor névből hatvankettő szerepel az adatbázisban, csupán Józsefből tizenhárom, ,s a közöttük fennálló rokoni viszonyok, illetve a többes kiutazás azonosítása lényegében megoldhatatlan maradt" (32.). A kimutatott utasszám természetesen nem a vándorforgalomban részt vettek abszolút száma - ennyit sikerült Fejősnek azonosítania. A számarány és a névlista ennek ellenére is sokatmondó.

A cigándi kivándorlás Fejős készítette adatbázisa úttörő munka, mivel „mindeddig nem készült egyetlen olyan magyar vonatkozású vizsgálat sem, amely egy település kivándorlóit az amerikai kikötők hivatalos regisztrációja, illetve a kivándorlókat szállító hajók utaslistái alapján vette volna számba" (33.). Az ilyen nem magyarországi hatósági nyilvántartások a lokális magyarországi kutatások számára is új lehetőségeket jelentenek (34.). A történeti forrásanyagot szóbeli emlékek egészítik ki, ezek cigándiakkal 2014-2017-ben készített interjúkból származnak.

A kivándorlás 1892-ben kezdődött Cigándon. Az egyik eredeti célállomás Kreischerville (1920 óta Charleston) volt, a New York Cityhez tartozó Staten Island délnyugati partján fekvő falu, melynek ,neve összeforrt a téglagyártással” (63.). Fejős részletesen bemutatja a vándorlás intenzitását, a migrációs útvonalakat, külön figyelmet fordít a „női történetekre” és a zsidó kivándorlókra is, és tárgyalja a hazatérőket és az új kivándorlókat is.

Mai digitális világunkban korábban elképzelhetetlen élményekre tehetünk szert a könyvet olvasva. Például a 82-83. oldalon megismerhetjük egy halálos kimenetelü gyári baleset Cigándról kivándorolt áldozatának történetét, akit a Pennsylvaniában levő duquesne-i magyar református temetőben temettek el 1926-ban. A szerencsétlenül járt embert Ócs Antalnak hívták, s Fejős könyvében színes fényképen láthatjuk sírkövét, abban a temetőben, amelyről megnyitásakor az Amerikai Magyar Népszava 1919. június 20-án azt írta: „A magya- 
rok temetöje Duquesne határában, gyönyörü helyen van, és már is 21 magyar alussza örök álmát ebben a temetőben.” Fejős ehhez hozzáteszi, hogy 2017 áprilisában ugyanitt 464 síremléket tartottak nyilván.

Az Együtt és külön, oda-vissza címü fejezet (87-100.) aprólékos, részletes elemzésekkel mutatja be a migrációt. A Cigándról Amerikába menők „összesen 257 hajójáratot vettek igénybe, s összesen 112 hajón ült cigándi illetőségü (vagy itt született) utas" (88.). Hogy csoportosan vagy egyénileg utaztak-e a cigándiak 1885 és 1928 között, azt a szerző saját adatbázisából készített táblázatban (90.) mutatja be, melyből kiderül, hogy egyedül utaztak 130 hajójáraton, ketten utaztak 39 hajójáraton, hárman 29-en, négyen ötön, s végül tízen utaztak a cigándiak egyetlen hajójáraton. Utóbbiak mind Hamburgból indultak 1907. március 7-én, s New Yorkba megérkezvén mindannyian Staten Islandre igyekeztek, egyikük Linoleumville-be, a többiek Kreischerville-be, a „,cigándi magyar faluba”. Fejös a Cigándon néhány éve végzett terepkutatásai során igyekezett összegyüjteni minden, az „amerikázással” kapcsolatos emléket, a szóbeliségben még élő történetet vagy a vándorlással kapcsolatos tárgyi emlékeket. Így aztán megtudjuk, hogy egy bizonyos Boros Antal háromszor fordult meg a két kontinens között, mindig hozott magával pénzt, sőt egyszer két kisfiának amerikai ruhákat is hozott, akikről a szerző közli egy 1912 körül készült fénykép másolatát is (95.), amiről elmondja, hogy pontosan kitől kapta, s hogy 2014. május 25-én interjúvolta meg a kép tulajdonosát Cigándon (194.).

A könyv egyik különleges értéke Kö Csáki József kézzel írt, verses önéletrajzának betűhív kiadása (203-291.) és az ezt elemző fejezet (101-107.). A cigándi parasztember 1915 és 1919 között vetette papírra az Egyesült Államokban életének krónikáját, amit 1956-ban adományozott Balassa Ivánnak, a sárospataki Rákóczi Múzeum akkori igazgatójának. Az önéletrajz legfőbb értéke az, hogy megmutatja az akkori magyarországi és amerikai munkavégzés és a munkáról való beszéd dimenzióit. Fejös a hunglish szavak, kifejezések magyarországi megfelelöit Bakó Elemér, Albert Tezla és Vázsonyi Endre munkái alapján precíz széljegyzetekben adja meg.

Az olvasó eligazodását Fejös Zoltán könyvében sokféle hasznos mutató is segíti. A Forrásokban (193-194.) tételesen fölsorolja a felhasznált utaslistákat, népszámlálásokat, anyakönyveket, hírlapokat és évkönyveket, archívumokat és az interjúalanyokat. A 82 tételt tartalmazó Képjegyzékben (195-197.) minden képről megtudjuk, hogy kit ábrázol, mikor készült, s kinek a tulajdona. A kétoldalas Név- és családtörténet-mutató (198-199.) mellett nagyon hasznos a „Cigándi vándormunkások, kivándorlók az amerikai kikötők nyilvántartása szerint, 1885-1936" címü lista (294-327.), amelyből az összes kivándorlóról olyan adatokat ismerhetünk meg, mint a lista utolsó tagjáról: Keisler Margit 1936. 07. 12.-én érkezett, huszonnyolc éves korában, La Havre-ból indult, s a Britannic hajón utazott, testvéréhez Keisler Hermanhoz jött, és úti célja a Washington ál- 
lambeli Seattle volt. Végül az Egyesült Államokban elhunyt cigándiak részleges jegyzéke hatvanöt kivándorlót tartalmaz (330-333.). Mindez nem hagy kétséget afelől, hogy Fejős Zoltán elérte egyik fö célját, vagyis megismerteti a mai cigándiakat múltjuk egy elfeledett darabjával (7.).

Noha Fejős minden eszközt és precizitást bevet, ami egy kulturális antropológustól és egy történésztől elvárható, könyve élvezetes olvasmány. Ezt úgy éri el, hogy hőseit állandóan emberközelbe hozza. Például részletesen leírja, s fényképekkel is gazdagon illusztrálja, miként történt az, amikor ,ötvenhét évvel elszakadásuk után [egy] anya és lánya találkozott egymással Floridában" (136.). A kiutazó cigándi asszonyt (a lányt) Ferihegyen tizenhét rokon búcsúztatta. Floridában aztán érzelmileg nem jött létre az a kapcsolat, amelyet a találkozástól vártak. Anya és lánya közel hatvan évet élt egymástól különválva, nem értették egymás világát. A találkozás élménye, az új ismeretségek $\mathrm{s}$ az új rokonok nem egymáshoz közelítették a két asszonyt, inkább erősítették a közöttük lévő különbségeket. Az iménti öt-hat sorban némileg parafrazáltam s rövidítettem Fejős tárgyszerű szövegét, de a követező idézettel drámai közelségbe hozza a szerző, mit is jelent az, hogy anya és lánya nem értették egymás világát: „A félreértések a tárgyak nyelvén is kifejeződtek. Ennek esete a »hatszáz dolláros bunda« története. Ez talán még a kiutazás elött történt. Nagymama egy ízben hatszáz dollárt küldött, hogy a lánya arra költse, amire akarja. Varratott belöle egy fekete bundát és lefényképeztette magát benne [itt Fejős közli a fényképet is]. A képet kiküldte az anyjának, hogy lássa, mire költötte a pénzt. »Nekem soha nem volt bundám « - jött a nem várt válasz, ami nagyon rosszul esett az asszonynak. Amikor ment ki, ajándékba vásárolt egy üveg tiszta, jó minőségű szilvapálinkát. Ez nagy szó volt akkoriban, hiszen hivatalosan csak fél liter szeszt lehetett kivinni. Az ajándék ennek legalább a duplája volt. Amikor átadta, az anyja nagyot nézett, és azt kérdezte: »Ti isztok otthon?«" (139.)

A kivándorlás és a helyi emlékezet címü fejezet (183-188.) annak felemlítésével kezdődik, hogy nincsenek már amerikás nagybácsik, nagynénik. A kivándorlási láz óta közel háromnemzedéknyi idő telt el, a nagy vándorlásról való tudás átörökítését „már csak tudatos módon, történetírói módszerekkel lehet biztosítani” (183.). Ez a könyv része ennek az átörökítési folyamatnak - írja a szerző. De több is annál - teszem hozzá -, mert nem csupán a cigándi embereknek meséli el, mutatja meg a közülük Amerikába vándoroltak történeteit, hanem szól a történészeknek és minden olyan társadalomkutatónak, aki a „magyar Amerikával” foglalkozik. Közhely, de leírom: Fejős cigándi könyve az utóbbiak számára alapmü, kötelező olvasmány, s egyben új kutatási irányokat nyitó, inspiráló alkotás.

Fejős Zoltán mostani könyve igényes, szép kiadvány, melynek értékéből nem von le semmit a néhány betủhiba (például Baló Elemér Bakó helyett [79.], 
Kestenbaum Ármin és Kesztenbaum a 168. oldalon). Szerfelett dicséretes az is, hogy ezt a könyvet nem egy tudományos műveket is kiadó vállalat, hanem egy bodrogközi kisváros önkormányzata adta ki - az egész magyar tudomány hasznára.

(Fejös Zoltán: „,Mert abban az időben lehetett vándorolni”: A cigándi amerikások emlékezete. Cigánd: Cigánd Város Önkormányzata, 2017. 336 o.)

Kontra Miklós

egyetemi tanár Károli Gáspár Református Egyetem Bölcsészettudományi Kar Magyar Nyelvtudományi Tanszék

URL1: New York Passenger Lists, 1820-1957. https://search.ancestry.com/search/db.aspx? $\mathrm{dbid}=7488$ 